Egyptian Poultry Science Journal

http://www.epsaegypt.com

ISSN: 1110-5623 (Print) - 2090-0570 (On line)

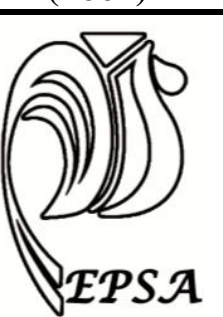

\title{
EFFECT OF SUPPLEMENTING DIET WITH SODIUM BENTONITE AND/OR ORGANIC CHROMIUM ON PRODUCTIVE, PHYSIOLOGICAL PERFORMANCE AND IMMUNE RESPONSE OF MATROUH CHICKENS STRAIN.
}

\section{1- DURING GROWTH PERIOD.}

\author{
W. Ezzat' ${ }^{1}$; A. E. El-Slamony ${ }^{1}$; A. M. Rizk ${ }^{1}$, I. A. Fathey ${ }^{2}$ and M.M. Sabry ${ }^{2}$ \\ ${ }^{1}$ Dept. Of Poult. Breed. Res. ${ }^{2}$ Dept. Of Poult. Nutr. Res. \\ Anim. Prod. Res. Insti., Agric. Res. Center, Dokki, Giza, Egypt.
}

Corresponding Author:Waheed Ezzat; E-mail: dr.waheed_ezzat@yahoo.com

Received: $15 / 08 / 2016$

Accepted: 30/08/2016

\begin{abstract}
The main objective of this study was to investigate the effect of sodium bentonite $(\mathrm{Na}-\mathrm{B})(0,5$ and $10 \mathrm{~g} / \mathrm{kg}$ diet $)$ and chromium picolinate $(\mathrm{CrPic})(0,800$ and 1200 $\mu \mathrm{g} \mathrm{Cr} / \mathrm{kg}$ diet) in the diet on growth performance, the mortality rate; some blood serum constituents, as well as the immune response and economic efficiency of male chicks of local strain Matrouh during the growing period. 540 one-day old male chicks were randomly chosen from a flock reared on the floor and distributed into 9 treatment groups (60 males / each treatment) in a factorial arrange. Feed with Na-B supplementation (5 and $10 \mathrm{~g} / \mathrm{kg}$ diet $)$ had a significant positive effect $(\mathrm{P} \leq 0.05)$ on body weight $(\mathrm{BW})$, body weight gain (BWG), and feed intake (FI), as well as, serum globulin, triodothyronine hormone (T3), glutathione peroxidase (GPX) and decrease in mortality rate and malonidialdehyde (MDA) values. However, feed conversion ratio (FCR), total antibody responses against SRBCs, total protein, albumin, growth hormone $(\mathrm{GH})$, cholesterol and calcium were insignificantly affected by these treatments, but they gave the highest net return and best economic efficiency $(\mathrm{P} \leq 0$. 01) compared to their controls at 12 wks of age. Supplementation of 800 or $1200 \mu \mathrm{g}$ CrPic $/ \mathrm{kg}$ diet significantly increased BW, BWG and improved FCR, as well as, a titer of SRBCs, serum total protein, albumin, globulin, and GH concentrations. While, the mortality rate and serum cholesterol were significant $(\mathrm{P} \leq 0.05)$ decreased. However, there were no significant differences among treatments in calcium, T3, MDA and GPX. Supplemented diets with CrPic gave the highest net return and best economic efficiency $(\mathrm{P} \leq 0.01)$ compared to their controls. Moreover, BW, BWG, FI and FCR, mortality rate, serum globulin and calcium influenced by the interaction between dietary Na-B and CrPic. Whereas, SRBCs, total protein, albumin, GH, cholesterol, T3, MDA and GPX were not significantly influenced by their interaction. It is clear that, supplementing the chick's diet with both $10 \mathrm{~g} \mathrm{Na-B}$ and $1200 \mu \mathrm{g} \mathrm{CrPic} / \mathrm{kg}$ diet alone or together is recommended for improving most of the growth performance, serum biochemical traits as well as improved immune responses and gave the highest net return and best economic efficiency during the growing period of Matrouh male chicks
\end{abstract}

Keywords: Sodium Bentonite- Chromium Picolinate- Growth Performance- Blood. 


\section{INTRODUCTION}

Bentonite is aluminosilicate (natural clay) conforming gut structure and has beneficial effects on feed conversion ratio and growth rate of broilers (Damiri et al., 2012). Bentonite as a feed added substance has been utilized effectively as a part of poultry feeds with no destructive impacts (Safaeikatouli et al., 2010). Salari et al., (2006) showed that 10 to $20 \mathrm{~g} \mathrm{Na}-\mathrm{B}$ per $\mathrm{kg}$ of the diet can be utilized as a pellet fastener with no adverse effect on broiler performance. Hepatic proteins alongside blood parts have been assessed as health indices in different studies (Akbarian et al., 2012). Bentonite has been utilized adequately as a feed additive in poultry feeds, with the swelling of bentonite, creating a lessening in the rate of feed travels through the digestive tract, allowing time for more successful use (Damiri et al., 2012). The gastrointestinal tract (GIT) expends around $20 \%$ of dietary energy and has 50 to $75 \%$ protein turnover rate for each day (Cant et al.1996). Almost 25\% of daily protein synthesis is emitted into the GIT to support digestive and obstruction usefulness. In addition, GIT has been an essential center of activity of phytogenic feed additives. Bentonite at $5 \%$ was the ideal level for the most extreme percent weight gain, particular growth rate and feed efficiency (Eya et al., 2008).

Chromium ( $\mathrm{Cr}$ ) is an essential element required for carbohydrate, fat, and protein metabolism (Chen et al., 2006). Dietary chromium supplementation advances the growth rate and feed efficiency of growing poultry, and these beneficial effects appear to be more noteworthy under heat stress (Onderci et al., 2005). Chromium is included a protein, digestion system (NRC, 1994) and is thought to have a part of a nucleic acid digestion system on the grounds that an expansion in stimulation of amino acid fuses into liver protein in vitro was watched (Weser and Column 1969).
The $\mathrm{Cr}$ affects the function of digestive enzyme (Pacheco et al., 2012). The $\mathrm{Cr}$ toxicity depends on the oxidation state and on blood, a large portion of Cr III binds with the protein molecules, and less quantity binds with oligopeptide. Sources of $\mathrm{Cr}$ are the drinking water, air and through ingestion (Assesm and Zhu 2007). Chromium propionate is an organic source of chromium absorbed more efficiently than few other organic chromium sources (Clodfelder et al., 2004). The essential part of $\mathrm{Cr}$ in a digestion system is to potentiate the activity of insulin through its nearness in an organometallic atom (the glucose resilience variable) (Anderson, 1999). Chromium is an insulin potentiator, subsequently, hypothesized to work as cell reinforcement (Preuss et al., 1997). Improvements in the immune response have been observed when organic forms of $\mathrm{Cr}$ were supplemented to broilers (Toghyani et al., 2007).

Therefore, the target of this study was to evaluate the effect of supplementing different levels of Na-B and CrPic in the diet on chick's performance, mortality rate, antibody response, some blood serum constituents and economic efficiency of local strain Matrouh male chicks during the growth period.

\section{MATERIALS AND METHODS}

The trial work of this study was carried out at the Inshas Poultry Research Station, Anim. Production Research Institute, Agriculture Research Center, Giza, Egypt, the experiment started from February until April 2016.

A 3x3 factorial arrangement experiment was performed at three levels of Na-B $(0,5$ or $10 \mathrm{~g} / \mathrm{kg}$ diet) and three levels of CrPic contained $12.27 \% \mathrm{Cr}(0,800$, or $1200 \mu \mathrm{g}$ $\mathrm{Cr} / \mathrm{kg}$ diet). 540 male chicks of Matrouh local strains at the first day of age were randomly chosen from a flock reared on the floor and distributed into 9 treatment groups (60 males / treatment). All the 
treatment groups had a nearly similar average body weight. Each group was divided into three replicates (20 males /each). The composition and chemical analysis of the experimental diet is presented in Table 1. It was an aflatoxin concentration in the cock's diet and contaminated naturally (6.73 micrograms / $\mathrm{kg}$ dry matter) during the growing period. The ingredients of bentonite are $\mathrm{SiO}_{2}$, $54.15 \% ; \mathrm{AL}_{2} \mathrm{O}_{3}, 17.78 \% ; \mathrm{Fe}_{2} \mathrm{O}_{3}, 4.31 \%$; $\mathrm{MgO}, 2.82 \% ; \mathrm{Na}_{2} \mathrm{O}, 2.12 \% ; \mathrm{CaO}, 2.87 \%$; $\mathrm{MnO}, 0.02 \% ; \mathrm{K}_{2} \mathrm{O}, 0.62 \% ; \mathrm{TiO}_{2}, 0.16 \%$; $\mathrm{P}_{2} \mathrm{O}_{5}, 0.06 \% ; \quad \mathrm{Cr}_{2} \mathrm{O}_{3}, \quad 0.003 \% ; \quad \mathrm{TOT} / \mathrm{S}$, $0.09 \%$; LOl, $14.9 \%$ (Abdel-Motelib et al. 2011). The mean value of the daily ambient temperature and relative humidity during that period in the house were $21.78 \pm 0.58$ ${ }^{\circ} \mathrm{C}$ and $47.28 \pm 2.19 \%$, respectively. The trial time frame stretched out for 12 weeks, from 1day - 12 weeks of age.

All experimental birds were kept under similar environmental conditions and exposed to 24 hours' light during the initial two days of age, 16 hours' light during 3-6 days of age and steady 14-hour light from 2 to 12 weeks of age. The chicks were fed ad libitum and fed starter diets from 0 to 8 wks and after that changed to grower diets to 12 wks of age (Table 1). Fresh water was available all the experimental periods. The mortality rate was calculated during the experimental period. The chicks were resolved examination against diseases. Individual body weight was recorded at first day, 4, 8 and 12 wks of age. Body weight gain, feed intake and feed conversion ratio were calculated at the interims from 0 to 4,4 to 8,8 to 12 and 0 to 12 wks of age. Feed conversion was calculated as $\mathrm{g}$ feed / $\mathrm{g}$ gain. The antibody response against SRBC was measured from 6 chicks in every treatment at 11 wks of age. The chicks were injected with $0.2 \mathrm{ml}$ of $9 \%$ SRBC in $0.9 \%$ saline. Serum tests were gathered on the 7th day of each implantation to choose threatening to SRBC essential immunizes titers, separately. Immune response creation was measured by an agglutination test using the Microtiter methodology (Trout et al., 1996).

At the end of the experimental period, 3 chicks were randomly chosen for each treatment, and blood tests were obtained from the brachial vein for serum total protein, albumin, $\mathrm{GH}$, cholesterol, calcium, T3, MDA and GPX determination. Blood serum was separated by centrifugation of blood at $3000 \mathrm{rpm}$ for $15 \mathrm{~min}$ and was then stored at $-20^{\circ} \mathrm{C}$ for analysis. Serum total protein, albumin, cholesterol and calcium concentrations were measured by spectrophotometer utilizing available commercial kits produced by Bio- analytic, Egypt. Globulins were estimated by subtraction of albumin value from the total protein value of each sample Serum was so isolated to quantify triodothyronine (T3) hormone level Radioimmunoassay (RIA) kits (diagnostic product's corporation, Los Angeles, USA) were utilized for carrying out these tests. Malonidialdehyde (MDA) and glutathione peroxidase (GPX) concentration in serum determined by the method of Valenzuela (1991) and Weydert and Cullen (2010), respectively.

Data obtained were statistically analyzed using the General Linear Model of SAS (2004). A factorial arrangement 3x3 was used, considering the sodium bentonite and chromium picolinate supplementation level as the main effects, as follows:

$\mathrm{Y}_{\mathrm{ijk}}=\mu+\mathrm{T}_{\mathrm{i}}+\mathrm{R}_{\mathrm{j}}+(\mathrm{TR})_{\mathrm{ij}}+\mathrm{e}_{\mathrm{ijk}}$ where:

$\mathrm{Y}_{\mathrm{ijk}}=$ An observation;

$\mu=$ Overall mean;

$\mathrm{T}=$ Effect of sodium bentonite supplementation level; $\mathrm{i}=(1,2$ and 3$)$;

$\mathrm{R}=$ Effect of chromium picolinate supplementation level; $\mathrm{j}=(1,2$ and 3$)$;

$\mathrm{TR}=$ Interaction effect due to sodium bentonite and chromium picolinate levels; $\mathrm{ij}=(1,2,3 \ldots . .9)$;

eijk $=$ Random error. 
Differences between treatments means were compared using Duncan's Multiple Range Test (Duncan, 1955).

\section{RESULTS AND DISCUSSION}

Body weight (BW) and body weight gain (BWG)

Results of BW and BWG of male chicks of Matrouh local as affected by $\mathrm{Na}-\mathrm{B}$ and $\mathrm{CrPic}$ and their interactions are summarized in Table 2.

Feed with Na-B supplementation (5 and 10 $\mathrm{g} / \mathrm{kg}$ diet $)$ significantly increased $(\mathrm{P} \leq 0.05)$ $\mathrm{BW}$ at 12 wks of age and BWG from 8 to 12 and 0 to 12 wks of age. These might be a direct result of $\mathrm{Na}-\mathrm{B}$ having the ability to upgrade, improve execution and supplement absorbability (Miazzo et al. 2005 and Salari et al. 2006). The improvement in final $\mathrm{BW}$ and $\mathrm{BWG}$ observed in the present study could have been due to the presence of $\mathrm{Na}-\mathrm{B}$ in the diet, which might have increased feed retention time through the gut of the chicks. Thus subjecting the nutrients to enzymatic action for quite a long time, or could have been due to the action of bentonite in enhancing digestibility of certain nutrients. These results are in agreement with those of Tauqir and Nawaz (2001) demonstrated that 1,2 and $3 \%$ Na-B enhanced $(\mathrm{P}>0.05)$ weight gain and final weight. Moreover, Pasha et al. (2008) reported similar enhancements in broilers by 0.5 and $1 \%$ Na-B.

Supplemented diets with 800 or $1200 \mu \mathrm{g}$ $\mathrm{CrPic} / \mathrm{kg}$ diet had a significant effect on $\mathrm{BW}$ at 8 and $12 \mathrm{wks}$ of age and BWG from 4-8 and 0-12 wks of age. These results are in agreement with those of Aslanian et al. (2011) who stated that male broiler feed $\mathrm{Cr}$ supplemented diet had higher BW and improved the BWG than the control diet $(\mathrm{P} \leq 0.05)$ from 21 to 42 days of age. Abdallah et al. (2013) indicated that CrPic supplementation, at 200, 400, 600 and 800 $\mathrm{ppb}$ levels, improved weight gain of Golden Montazah chickens. Samanta et al.
(2008) found that live weight gains and protein and conversion efficiency of feed protein to muscle protein improved owing to $\mathrm{Cr}^{3+}$ supplementation $\left(0.5 \mathrm{mg} \mathrm{Cr} \mathrm{Cr}^{3+} \mathrm{kg}^{-1}\right.$ diet $) \quad(\mathrm{P} \leq 0.05) \quad$ Also, CrPic supplementation improved growth performance of broiler (Jackson et al. 2008). They proved to increase in BW by supplementing $\mathrm{Cr}$ may be a direct result of protein absorption framework (Anderson, 1999). Likewise, $\mathrm{Cr}$ is accepted as a basic part in crucial section of the glucose versatility segments (GTF).

The interactions between $\mathrm{Na}-\mathrm{B}$ and $\mathrm{CrPic}$ had a significant effect on $\mathrm{BW}$ at $12 \mathrm{wks}$ of age and BWG from 8-12 and 0-12 wks of age.

Feed intake $(\mathrm{FI})$ and feed conversion ratio (FCR):

Results of FI and FCR of male Matrouh chicks as affected by $\mathrm{Na}-\mathrm{B}$ and $\mathrm{CrPic}$ and their interactions are summarized in Table 3.

Feed with Na-B supplementation (5 and 10 $\mathrm{g} / \mathrm{kg}$ diet) had a significantly increased $(\mathrm{P} \leq 0.05)$ value of $\mathrm{FI}$ from $4-8,8-12$ and 0 12 wks of age. Moreover, FCR was insignificantly affected by these treatments. These results are in agreement with those of Damiri et al. (2012), who stated that chickens fed diets contained SB consumed more feed; and showed greatest feed utilization when broilers were fed ration containing $0.75 \%$ and $2.25 \% \mathrm{Na}-\mathrm{B}$, while minimum FI was noted in $3.75 \%(\mathrm{P} \leq 0.05)$ treatment. Pasha et al. (2008), used two bentonite levels $(0.5 \%$ and $1.0 \%)$ in broiler diets and reported more FI in chicks fed higher levels of Na-B (1\% Na-B) than their control. While, Tauqir and Nawaz, (2001) found decreased in FI and had no significant effect on FCR of broiler chicks fed diet including 2, 3 and 4\% Na-B. These may be a direct result of increased time of digestion in linen and more use of supplements (Damiri et al., 2012).

Supplemented diets with 800 or $1200 \mu \mathrm{g}$ $\mathrm{CrPic} / \mathrm{kg}$ diet had no significant effect on 
FI during all the experimental periods (except at 8 to 12 weeks of age) and improved FCR from 4-8, 8-12 and 0-12 wks of age. Anandhi et al. (2006) found that FI of broilers was not improved by supplementation of up to $750 \mu \mathrm{g} / \mathrm{kg}$ of chromium as chromium picolinate. Other reports demonstrated that $\mathrm{Cr}$ supplementation of broiler diets (1.5 and $2.5 \mathrm{mg} \mathrm{Cr} / \mathrm{kg}$ ) significantly improved FCR from 1-6 weeks of age (El-Kaiaty et al. 2005). Abdallah et al. (2013) indicated that CrPic supplementation, at 200, 400, 600 and $800 \mathrm{ppb}$ levels, did not affect feed consumption of both sexes but, improved FCR of Golden Montazah chickens.

The interactions between $\mathrm{Na}-\mathrm{B}$ and $\mathrm{CrPic}$ had significant effect on FI from 4-8, 8-12 and $0-12$ wks of age and FCR from 8-12 and 0-12 wks of age.

Mortality rate:

The mortality rate was $13.9,10.0$ and $7.2 \%$ for the control and the treated groups received Na-B, respectively (Figure 1). The results were in accordance with the findings of Aghashahi et al. (2015), who found that the mortality rate of broiler chickens tended to decrease in $\mathrm{Na}-\mathrm{B}$ supplemented group $(\mathrm{P} \leq 0$. 01). Barmase et al. (1990) reported a significant reduction in mortality of broilers upon addition of 0.5 per cent bentonite to $0.5-\mathrm{ppm}$ aflatoxin containing diets. The decrease in mortality rate by $\mathrm{Na}-\mathrm{B}$ may be due to decreased aflatoxin uptake, which may diminish its impact on body organs (Zaki et al. 2008).

The mortality rate was $13.3,10.0$ and $7.8 \%$ for the control and treated groups received CrPic, respectively (Figure 2). The results were in accordance with the findings of Lien et al. (1999) who stated that supplemental dietary chromium as $\mathrm{CrPic}$ decreased mortality and alters glucose metabolism in chickens. Ibraham (2005) reported that mortality rates of broilers were $10.0,4.0,2.0,7.5,4.0$, and $7.5 \%$ for the control and treated groups received $\mathrm{Cr}$ $(10,20,30,40$ or $50 \mathrm{mg} \mathrm{Cr} / \mathrm{kg} \mathrm{diet})$, respectively. It was proved that mortality rates decreased in groups received $\mathrm{Cr}$ supplemented with the diets up to $50 \mathrm{mg}$ $\mathrm{Cr} / \mathrm{kg}$ compared to control group. Jackson et al. (2008) reported that dietary supplementation of $\mathrm{Cr}$ as $\mathrm{CrPic}$ (200 and $400 \mathrm{ppb})$ decreased mortality in broiler chicks in the finishing period.

The mortality rate was decreased in the groups received Na-B, $\mathrm{CrPic}$ in combination or alone as compared with their control (Figure 3). Mortality rate was $18.3,6.7$ and $5.0 \%$ for the control and treated groups received $\mathrm{Na}-\mathrm{B} \quad(10 \mathrm{~g} / \mathrm{kg})$ $+800 \mu \mathrm{g} \mathrm{CrPic} / \mathrm{kg}$ or Na-B $(10 \mathrm{~g} / \mathrm{kg})+1200$ $\mu \mathrm{g} \mathrm{CrPic} / \mathrm{kg}$, respectively.

Antibody response and blood constituents:

Results of antibody response and blood constituents of male Matrouh chicks as affected by $\mathrm{Na}-\mathrm{B}$ and $\mathrm{CrPic}$ and their interactions at the end of the experimental period are summarized in Table 4.

Feed with Na-B supplementation (5 and 10 $\mathrm{g} / \mathrm{kg}$ diet $)$ significantly increased $(\mathrm{P} \leq 0.05)$ values of serum globulin, T3 hormone, glutathione peroxidase (GPx) enzyme activity and decreased MDA values. However, there is no significant difference among treatments in total antibody response against SRBCs, total protein, albumin, growth hormone (GH), cholesterol and calcium (Table 4). These results are in agreement with those of Aghashahi et al. (2015) reported that the Na-B increased T3 concentration at day 35 of the experiment $(\mathrm{P} \leq 0.05)$ and no significant difference was found between the groups concerning $\mathrm{GH}$ concentrations $(\mathrm{P} \leq 0.05)$ compared to control in broiler chicks. Khanedar et al. (2012) found that the addition of bentonite ( 1 or $1.5 \%$ from $\mathrm{Na}-\mathrm{B}$ or $\mathrm{Ca}-\mathrm{B})$ to the diet had no significant effect on the protein and albumin. El-Abd (2014) indicated that, there is no significant difference among treatments $(0,4 \%$ and $6 \%$ bentonite) in total protein, globulin, creatinine, 
cholesterol, LDL, HDL and triglyceride of Japanese quail chicks.

Supplemented diets with 800 or $1200 \mu \mathrm{g}$ $\mathrm{CrPic} / \mathrm{kg}$ diet had a significant $(\mathrm{P} \leq 0.05$ or $\mathrm{P} \leq 0.01)$ a linear increase in the titer of SRBCs, serum total protein, albumin, globulin and GH concentrations. While, serum cholesterol significantly $(\mathrm{P} \leq 0.05)$ decreased. However, there is no significant difference among treatments in calcium, T3, MDA and GPX (Table 4). These results were in agreement with those obtained by Bahrami et al. (2012) who demonstrated that both 800 and 1,200 ppb of $\mathrm{Cr}$ as $\mathrm{Cr}-1-$ Met significantly increased antibody titers of broiler chicks compared to the control group $(\mathrm{P} \leq 0.01)$ at 30 days of age. Abdallah et al. (2013) found that antibody response against SRBC (IgG) of Golden Montazah laying hens was significantly ( $P$ $\leq 0.05$ ) higher in 48-week old laying hens fed $800 \mathrm{ppb} \mathrm{Cr}$ differentiated and control or 200,400 and $600 \mathrm{ppb}$ treatment groups. ElHommosany (2008) showed that total antibody and $\operatorname{IgG}$ titers against SRBCs were significantly higher in quail chicks received $\mathrm{Cr}$ differentiated and those of controls at secondary immune responses. The upgrade of immune response via $\mathrm{Cr}$ supplementation may be because of their antioxidant property. It reasons to protect immature lymphocytes from harm from free radical because of oxidation chromium supplementation is seen to improve the immune response, either through an immediate impact on the cytokines (Borgs and Mallard, 1998) or through the roundabout impact of decreasing the glucocorticosteroid levels (Samanta et al. 2008). Uyanik et al. (2002) who showed that broiler chicks fed 20, 40, or $80 \mu \mathrm{g}$ $\mathrm{Cr} / \mathrm{kg}$ diet for 44 days, increased lymphocyte counts, total antibody, IgG, and $\mathrm{IgM}$ titers. All levels of $\mathrm{Cr}$ increased the cell-mediated response to phytohemagglutinin. In the same respect, Rosebrough and Steele (1981) found that supplemented $\mathrm{Cr}$ in turkey poultry diets increased rate of glucose utilization and immune response, which explains the decreased mortality rate observed. On the other hand, Eshra (2005) found a direct increase in blood total protein levels with increasing dietary supplementation of $\mathrm{Cr}$ yeast in chicken. The increase in plasma protein and Globulin in the chickens that were supplemented with 800 or $1200 \mu \mathrm{g}$ $\mathrm{CrPic} / \mathrm{kg}$ diet increased protein synthesis in the supplemented group over the control group, which resulted in highly live body weight and weight gain, the group as compared with the control group. The increase in serum albumin might be because of increased amino acid synthesis within the liver, suggesting that $\mathrm{Cr}$ may improve amino acid synthesis (MoonsieShageer and Mowat. 1993). Additionally, Uyanik et al. (2002) watched a diminishment in plasma total lipid, cholesterol by adding $\mathrm{Cr}$ and represented that, the decrease in lipid parameters could result from the increasing activity of insulin that discouraged the unsaturated fat amalgamation by increasing glycogen build up. Independently or as a blend supplemental Vit. $\mathrm{C}$ and $\mathrm{Cr}$ brought about abatement in MDA focus (Tawfeek et al. 2014). Attia et al. (2015) stated that serum MDA and cholesterol focus diminished with dietary $\mathrm{Cr}$. However, Ibrahim et al. (2010) reported that blood calcium and T3 concentration was not influenced significantly $(\mathrm{p} \leq 0.05)$ by adding different levels of chromium yeast $(0.5,1,1.5$ and 2 $\mathrm{mg}$ Cr-yeast $/ \mathrm{kg}$ ) into broiler diets. The same result was recorded by Mostafa (2007). Al-Bandr et al. (2010) found that blood calcium was not influenced by including $\mathrm{Cr}$ into the diets. Sahin et al. (2002) showed that adding $\mathrm{Cr}$ to broiler diet expanded serum $\mathrm{Ca}$. A possible illumination for the effect of $\mathrm{Cr}$ supplementation on $\mathrm{Ca}$ absorption framework may be a direct result of that, this mineral $(\mathrm{Cr})$ strives for the same limiting areas. 
Results showed that calcium of the chicks was significantly $(\mathrm{P} \leq 0.05)$ influenced by interactions between dietary sodium bentonite and organic chromium, whereas, SRBCs, total protein, albumin, globulin, GH, cholesterol, T3, MDA and GPX were not significantly affected by the interaction at the end of the experimental period.

Economic efficiency:

Results of economic efficiency of male Matrouh chicks as affected by Na-B and $\mathrm{CrPic}$ and their interactions at the end of the experimental period are summarized in Table 5.

Data in Table 5 indicate that feeding chick diets supplemented with Na-B at levels of 5 and $10 \mathrm{~g} / \mathrm{kg}$ diet gave the highest net return and best economic efficiency $(\mathrm{P} \leq 0.01)$ compared to those feds the control diet. These results are in agreement with those obtained by Fatouh et al. (2012) who found improved in EEF values of kampell ducks at 24.98 and $31.66 \%$ of the groups fed 0.50 and $1.0 \% \mathrm{Na}-\mathrm{B}$, respectively, as compared to the control group during the studied laying period from 25 to 48 weeks of age. El-Abd (2014) reported that according to sodium bentonite levels, the Japanese quail chicks fed diet containing $6 \%$ recorded the highest values of economic efficiency, followed by chicks, which fed a diet containing $4 \%$ sodium bentonite.
Supplemented diets with 800 or $1200 \mu \mathrm{g}$ $\mathrm{CrPic} / \mathrm{kg}$ diet had a significant $(\mathrm{P} \leq 0.01)$ a linear increase in the net return and economic efficiency compared to those fed the control diet. These results are in agreement with those obtained by Mohammed et al. (2014) who found that organic chromium $(0.5 \mathrm{ppm} \quad \mathrm{Cr} / \mathrm{kg})$ supplemented group showed the highest return and also the highest total costs while, the control group showed the lowest return and the lowest total costs.

Regarding the interaction effect, results in Table 5 demonstrated that the best economic efficiency value was obtained with chicks fed diets containing $\mathrm{Na}-\mathrm{B}$ $(10 \mathrm{~g} / \mathrm{kg})+1200 \mu \mathrm{g} \mathrm{CrPic} / \mathrm{kg}$ followed by $\mathrm{Na}-\mathrm{B} \quad(10 \mathrm{~g} / \mathrm{kg}) \quad+800 \quad \mu \mathrm{g} \quad \mathrm{CrPic} / \mathrm{kg}$ as compared to the control group.

\section{CONCLUSION}

Based on these results, it can be concluded that the present study indicated that Supplemented chick's diets with either $10 \mathrm{~g}$ $\mathrm{Na}-\mathrm{B}$ or $1200 \mu \mathrm{g} \mathrm{CrPic} / \mathrm{kg}$ diet alone or together may improve the growth performance, serum biochemical traits as well as improved immune responses and give the highest net return and best economic efficiency during the growing period of male Matrouh chicks. 
Table (1): The composition of the experimental basal diets.

\begin{tabular}{|l|c|c|}
\hline \multicolumn{1}{|c|}{ Ingredients } & Starter diet & Grower diet \\
& $(\mathbf{\% )}$ & $\mathbf{( \% )}$ \\
\hline Yellow corn & 59.84 & 65.40 \\
Soya bean 44\% & 24.20 & 22.00 \\
Wheat bran & 8.20 & 3.00 \\
Corn gluten 60\% & 4.00 & ----- \\
Di Ca P export & 1.53 & 1.39 \\
Limestone & 1.52 & 7.44 \\
Salt ( NaCl ) & 0.37 & 0.30 \\
*Premix & 0.30 & 0.30 \\
L Methionine & 0.04 & 0.17 \\
Total & 100.00 & 100.00 \\
Protein & 19.0 & 16.05 \\
Metabolizable energy (M.E.) & 2800 & 2726.76 \\
Crude fiber (C. F.) & 4.124 & 3.375 \\
Calcium & 0.995 & 3.804 \\
Total Phosphorous & 0.692 & 0.619 \\
Lysine & 0.949 & 0.820 \\
Methionine & 0.403 & 0.490 \\
\hline
\end{tabular}

*Premix added to the $1 \mathrm{~kg}$ of diet including vit.A 10000 I.U; vit. D3 $2000 \mathrm{I} . \mathrm{U}$; vit. E $15 \mathrm{mg}$; vit. K3 $1 \mathrm{mg}$; vit B1 1mg; vit. B2 5 mg; vit. B12 $10 \mu \mathrm{g}$; vit B6 1.5mg; Niacin 30mg; Pantothenic acid $10 \mathrm{mg}$; folic acid $1 \mathrm{mg}$; Biotin $50 \mu \mathrm{g}$; choline $300 \mathrm{mg}$; zinc $50 \mathrm{mg}$; copper $4 \mathrm{mg}$; iodine 0.3 $\mathrm{mg}$; iron 30mg; selenium 0.1mg; manganese $60 \mathrm{mg}$; cobalt $0.1 \mathrm{mg}$ and carrier $\mathrm{CaCo} 3$ up to $1 \mathrm{~kg}$. **According to Feed composition tables for Animal \& Poultry feedstuffs used in Egypt (2001). 
Table (2): Body weight and body weight gain $(\bar{X} \pm S E)$ of male Matrouh chicks as affected by different levels of dietary sodium bentonite and organic chromium and their interactions during the different experimental periods.

\begin{tabular}{|c|c|c|c|c|c|c|c|c|c|}
\hline \multicolumn{2}{|c|}{ Items } & \multicolumn{4}{|c|}{$\begin{array}{c}\text { Body weight } \\
\text { (gm) }\end{array}$} & \multicolumn{4}{|c|}{$\begin{array}{c}\text { Body weight gain } \\
(\mathrm{gm})\end{array}$} \\
\hline \multirow{7}{*}{\multicolumn{2}{|c|}{$\begin{array}{l}\text { SB }(g / k g): \\
0 \\
5 \\
10 \\
\text { Cr / Kg diet } \\
(\mu g) .\end{array}$}} & Initial & 4 weeks & 8 weeks & 12 weeks & 0-4 week & \begin{tabular}{l|l}
$4-8$ week &
\end{tabular} & 8-12 week & 0-12 week \\
\hline & & NS & NS & $\mathrm{NS}$ & $* *$ & NS & NS & $*$ & $* *$ \\
\hline & & $31.93 \pm 0.25$ & $192.60 \pm 5.22$ & $488.36 \pm 5.99$ & $763.78 \pm 11.55^{\mathrm{b}}$ & $160.68 \pm 5.17$ & $295.76 \pm 7.48$ & $275.42 \pm 12.99^{b}$ & $731.86 \pm 11.51^{b}$ \\
\hline & & $31.80 \pm 0.30$ & $204.33 \pm 6.60$ & $499.25 \pm 8.05$ & $824.76 \pm 10.43^{a}$ & $172.53 \pm 6.48$ & $294.92 \pm 10.24$ & $325.51 \pm 10.77^{\mathrm{a}}$ & $792.97 \pm 10.38^{\mathrm{a}}$ \\
\hline & & $31.46 \pm 0.30$ & $209.53 \pm 6.83$ & $507.64 \pm 7.53$ & $817.49 \pm 20.00^{\mathrm{a}}$ & $178.08 \pm 6.74$ & $298.11 \pm 8.09$ & $309.85 \pm 16.92^{\mathrm{ab}}$ & $786.03 \pm 19.95^{\mathrm{a}}$ \\
\hline & & & NS & $* *$ & $* *$ & NS & & NS & \\
\hline & & $31.80 \pm 0.30$ & $196.95 \pm 5.74$ & $472.36 \pm 3.81^{b}$ & $757.58 \pm 12.97^{b}$ & $165.15 \pm 5.64$ & $275.42 \pm 6.23^{b}$ & $285.22 \pm 13.89$ & $725.78 \pm 12.89^{b}$ \\
\hline \multirow{2}{*}{\multicolumn{2}{|c|}{$\begin{array}{l}0 \\
800 \\
1200 \\
\text { Interaction } \\
\text { effects: } \\
\end{array}$}} & $31.72 \pm 0.26$ & $199.47 \pm 6.78$ & $506.37 \pm 5.73^{\mathrm{a}}$ & $819.65 \pm 11.76^{a}$ & $167.76 \pm 6.65$ & $306.89 \pm 7.69^{\mathrm{a}}$ & $313.29 \pm 12.30$ & $787.94 \pm 11.75^{\mathrm{a}}$ \\
\hline & & $\begin{array}{l}31.67 \pm 0.31 \\
\mathrm{NS}\end{array}$ & $\begin{array}{c}210.04 \pm 6.46 \\
\text { NS }\end{array}$ & $\begin{array}{l}516.53 \pm 7.61^{\mathrm{a}} \\
\mathrm{NS}\end{array}$ & $\begin{array}{c}828.80 \pm 17.02^{\mathrm{a}} \\
* *\end{array}$ & $178.38 \pm 6.45$ & $306.49 \pm 9.50^{\mathrm{a}}$ & $312.27 \pm 16.56$ & $797.14 \pm 16.99^{\mathrm{a}}$ \\
\hline $\begin{array}{c}\mathrm{SB} \\
(\mathrm{g} / \mathrm{kg}) \\
\end{array}$ & $\begin{array}{c}\mathrm{Cr} / \mathrm{Kg} \\
(\mu \mathrm{g})\end{array}$ & & & & & & & & \\
\hline \multirow{4}{*}{0} & 0 & $32.09 \pm 0.41$ & $186.87 \pm 10.0$ & $473.33 \pm 9.01$ & $750.71 \pm 11.11^{\text {ed }}$ & $154.78 \pm 9.87$ & $286.47 \pm 15.15$ & $277.38 \pm 15.01^{\mathrm{ab}}$ & $718.62 \pm 10.81^{\mathrm{de}}$ \\
\hline & 800 & $31.83 \pm 0.36$ & $196.05 \pm 9.45$ & $497.08 \pm 12.76$ & $771.05 \pm 11.38^{\text {cde }}$ & $164.22 \pm 9.49$ & $301.04 \pm 15.53$ & $273.96 \pm 14.99^{\mathrm{ab}}$ & $739.21 \pm 11.21^{\mathrm{cde}}$ \\
\hline & 1200 & $31.85 \pm 0.56$ & $194.88 \pm 8.83$ & $494.67 \pm 7.33$ & $769.58 \pm 32.49^{\text {cde }}$ & $163.03 \pm 8.60$ & $299.79 \pm 8.61$ & $274.92 \pm 35.63^{\mathrm{ab}}$ & $737.74 \pm 32.49^{\text {cde }}$ \\
\hline & 0 & $31.79 \pm 0.60$ & $203.85 \pm 8.31$ & $467.92 \pm 5.42$ & $804.42 \pm 18.50^{\mathrm{bcd}}$ & $172.07 \pm 8.23$ & $264.07 \pm 6.56$ & $336.50 \pm 17.59^{a}$ & $772.63 \pm 18.37^{\mathrm{bcc}}$ \\
\hline \multirow[t]{2}{*}{5} & 800 & $32.05 \pm 0.50$ & $205.00 \pm 15.5$ & $504.50 \pm 6.56$ & $827.83 \pm 13.94^{\mathrm{abc}}$ & $172.95 \pm 15.28$ & $299.51 \pm 12.27$ & $323.33 \pm 16.43^{\mathrm{a}}$ & $795.78 \pm 13.74^{\mathrm{abc}}$ \\
\hline & 1200 & $31.56 \pm 0.54$ & $204.14 \pm 11.60$ & $525.33 \pm 15.8$ & $842.04 \pm 20.70^{\mathrm{ab}}$ & $172.58 \pm 11.26$ & $321.20 \pm 23.30$ & $316.71 \pm 23.70^{\mathrm{a}}$ & $810.48 \pm 20.66^{a b}$ \\
\hline \multirow{3}{*}{10} & 0 & $31.53 \pm 0.57$ & $200.12 \pm 11.58$ & $475.84 \pm 5.55$ & $717.63 \pm 21.97^{\mathrm{e}}$ & $168.60 \pm 11.19$ & $275.72 \pm 8.54$ & $241.79 \pm 22.75^{\mathrm{b}}$ & $686.10 \pm 21.80^{\mathrm{e}}$ \\
\hline & 800 & $31.27 \pm 0.50$ & $197.37 \pm 11.37$ & $517.50 \pm 9.29$ & $860.08 \pm 16.52^{a b}$ & $166.10 \pm 10.92$ & $320.13 \pm 12.55$ & $342.58 \pm 23.37^{\mathrm{a}}$ & $828.81 \pm 16.51^{a b}$ \\
\hline & 1200 & $31.59 \pm 0.57$ & $231.11 \pm 8.44$ & $529.58 \pm 11.91$ & $874.77 \pm 17.65^{\mathrm{a}}$ & $199.53 \pm 8.90$ & $298.47 \pm 15.45$ & $345.18 \pm 21.57^{\mathrm{a}}$ & $843.19 \pm 17.13^{\mathrm{a}}$ \\
\hline
\end{tabular}

Means having different letters in the same column are significantly different $\quad *=(\mathrm{P}<0.05), \quad * *=(\mathrm{P}<0.01)$; NS= Not significant 
Table (3): Feed intake and feed conversion ratio $(\bar{X} \pm S E)$ of male Matrouh chicks as affected by different levels of dietary sodium bentonite and organic chromium and their interactions during the different experimental periods.

\begin{tabular}{|c|c|c|c|c|c|c|c|c|c|}
\hline \multicolumn{2}{|c|}{ Items } & \multicolumn{4}{|c|}{ Feed intake (gm) } & \multicolumn{4}{|c|}{ Feed conversion ratio } \\
\hline & & 0-4 week & $4-8$ week & 8-12 week & 0-12 week & 0-4 week & 4-8 week & 8-12 week & 0-12 week \\
\hline \multirow{5}{*}{\multicolumn{2}{|c|}{$\begin{array}{l}\mathrm{SB}(\mathrm{g} / \mathrm{kg}): \\
0 \\
5 \\
10 \\
\mathrm{Cr} / \mathrm{Kg} \text { diet } \\
(\mu \mathrm{g}) .\end{array}$}} & $\mathrm{NS}$ & $* *$ & $*$ & $*$ & NS & $\mathrm{NS}$ & NS & NS \\
\hline & & $428.02 \pm 11.15$ & $964.02 \pm 6.52^{\mathrm{b}}$ & $1528.77 \pm 11.78^{b}$ & $2920.81 \pm 25.45^{\mathrm{b}}$ & $2.69 \pm 0.12$ & $3.56 \pm 0.1$ & $5.62 \pm 0.23$ & $4.11 \pm 0.06$ \\
\hline & & $434.74 \pm 12.71$ & $985.02 \pm 13.25^{b}$ & $1573.48 \pm 27.62^{\mathrm{a}}$ & $2993.23 \pm 35.63^{\mathrm{a}}$ & $2.54 \pm 0.10$ & $3.4 \pm 0.17$ & $4.87 \pm 0.15$ & $3.79 \pm 0.08$ \\
\hline & & $440.62 \pm 11.54$ & $1044.79 \pm 13.16^{\mathrm{a}}$ & $1536.94 \pm 13.12^{\mathrm{ab}}$ & $3022.34 \pm 20.23^{\mathrm{a}}$ & $2.51 \pm 0.13$ & $3.26 \pm 0.09$ & $5.19 \pm 0.46$ & $3.79 \pm 0.16$ \\
\hline & & NS & NS & $* *$ & NS & NS & * & $*$ & $* *$ \\
\hline & $431.73 \pm 11.89$ & $995.82 \pm 14.28$ & $1587.53 \pm 24.02^{\mathrm{a}}$ & $3015.07 \pm 37.01$ & $2.65 \pm 0.15$ & $3.64 \pm 0.11^{\mathrm{a}}$ & $5.77 \pm 0.41^{\mathrm{a}}$ & $4.17 \pm 0.1^{\mathrm{a}}$ \\
\hline \multicolumn{2}{|c|}{800} & $424.71 \pm 11.22$ & $1002.25 \pm 19.75$ & $1532.11 \pm 11.81^{\mathrm{b}}$ & $2959.06 \pm 30.41$ & $2.56 \pm 0.12$ & $3.29 \pm 0.13^{b}$ & $4.96 \pm 0.22^{b}$ & $3.77 \pm 0.09^{b}$ \\
\hline \multirow{2}{*}{\multicolumn{2}{|c|}{$\begin{array}{l}1200 \\
\text { Interaction } \\
\text { effects: }\end{array}$}} & $446.94 \pm 11.37$ & $995.76 \pm 15.26$ & $1519.55 \pm 13.11^{b}$ & $2962.24 \pm 21.64$ & $2.52 \pm 0.1$ & $3.28 \pm 0.12^{b}$ & $4.95 \pm 0.23^{b}$ & $3.74 \pm 0.1^{\mathrm{b}}$ \\
\hline & & NS & $*$ & $* *$ & $*$ & NS & NS & $*$ & * \\
\hline \multicolumn{10}{|c|}{\begin{tabular}{c|c|}
$\begin{array}{c}\mathrm{SB} \\
(\mathrm{g} / \mathrm{kg})\end{array}$ & $\begin{array}{c}\mathrm{Cr} / \mathrm{Kg} \\
(\mu \mathrm{g})\end{array}$ \\
\end{tabular}} \\
\hline \multirow{4}{*}{0} & 0 & $421.52 \pm 22.57$ & $956.92 \pm 12.18^{d}$ & $1528.34 \pm 21.17^{b}$ & $2906.78 \pm 55.91^{\mathrm{c}}$ & $2.78 \pm 0.39$ & $3.57 \pm 0.17$ & $5.60 \pm 0.55^{\mathrm{ab}}$ & $4.14 \pm 0.18^{\mathrm{a}}$ \\
\hline & 800 & $421.38 \pm 18.47$ & $964.30 \pm 13.53^{\mathrm{cd}}$ & $1524.64 \pm 23.72^{\mathrm{b}}$ & $2910.32 \pm 54.57^{c}$ & $2.57 \pm 0.17$ & $3.61 \pm 0.26$ & $5.64 \pm 0.45^{\mathrm{ab}}$ & $4.09 \pm 0.04^{\mathrm{a}}$ \\
\hline & 1200 & $441.14 \pm 22.60$ & $970.85 \pm 11.43^{\mathrm{cd}}$ & $1533.33 \pm 25.17^{b}$ & $2945.32 \pm 34.81^{\mathrm{bc}}$ & $2.71 \pm 0.06$ & $3.5 \pm 0.13$ & $5.62 \pm 0.33^{\mathrm{ab}}$ & $4.10 \pm 0.04^{\mathrm{a}}$ \\
\hline & 0 & $431.33 \pm 25.91$ & $1017.18 \pm 22.24^{\mathrm{bc}}$ & $1672.69 \pm 21.77^{\mathrm{a}}$ & $3121.2 \pm 26.39^{\mathrm{a}}$ & $2.51 \pm 0.04$ & $3.87 \pm 0.23$ & $5.02 \pm 0.36^{\mathrm{b}}$ & $4.05 \pm 0.09^{\mathrm{a}}$ \\
\hline \multirow[t]{3}{*}{5} & 800 & $421.06 \pm 20.40$ & $966.19 \pm 13.94^{\mathrm{cd}}$ & $1518.22 \pm 22.07^{b}$ & $2905.47 \pm 15.56^{c}$ & $2.49 \pm 0.27$ & $3.24 \pm 0.14$ & $4.70 \pm 0.11^{b}$ & $3.66 \pm 0.05^{b}$ \\
\hline & 1200 & $451.82 \pm 24.57$ & $971.67 \pm 25.19^{\text {cd }}$ & $1529.52 \pm 27.84^{b}$ & $2953.01 \pm 38.01^{\mathrm{bc}}$ & $2.63 \pm 0.19$ & $3.07 \pm 0.28$ & $4.88 \pm 0.29^{b}$ & $3.65 \pm 0.08^{b}$ \\
\hline & 0 & $442.33 \pm 20.19$ & $1013.34 \pm 25.80^{\mathrm{bcd}}$ & $1561.56 \pm 16.83^{b}$ & $3017.22 \pm 33.39^{\mathrm{abc}}$ & $2.67 \pm 0.29$ & $3.49 \pm 0.14$ & $6.69 \pm 0.91^{\mathrm{a}}$ & $4.33 \pm 0.23^{\mathrm{a}}$ \\
\hline \multirow[t]{2}{*}{10} & 800 & $431.67 \pm 26.76$ & $1076.26 \pm 13.93^{\mathrm{a}}$ & $1553.46 \pm 16.44^{\mathrm{b}}$ & $3061.39 \pm 3.61^{\mathrm{ab}}$ & $2.62 \pm 0.26$ & $3.02 \pm 0.05$ & $4.54 \pm 0.01^{\mathrm{b}}$ & $3.56 \pm 0.06^{b}$ \\
\hline & 1200 & $447.85 \pm 20.17$ & $1044.76 \pm 15.07^{\mathrm{ab}}$ & $1495.79 \pm 15.03^{b}$ & $2988.4 \pm 49.32^{\mathrm{bc}}$ & $2.25 \pm 0.10$ & $3.27 \pm 0.11$ & $4.35 \pm 0.12^{\mathrm{b}}$ & $3.46 \pm 0.04^{b}$ \\
\hline
\end{tabular}

Means having different letters in the same column are significantly different $\quad *=(\mathrm{P}<0.05), \quad * *=(\mathrm{P}<0.01)$; NS= Not significant 


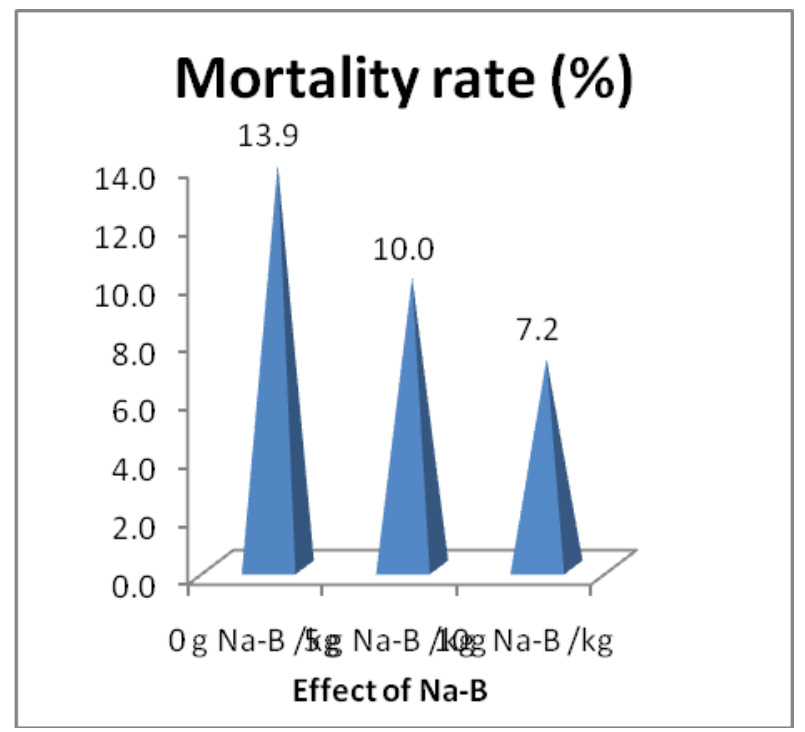

Figure1. Effect of Na-B on mortality rate

\section{Mortality rate (\%)}

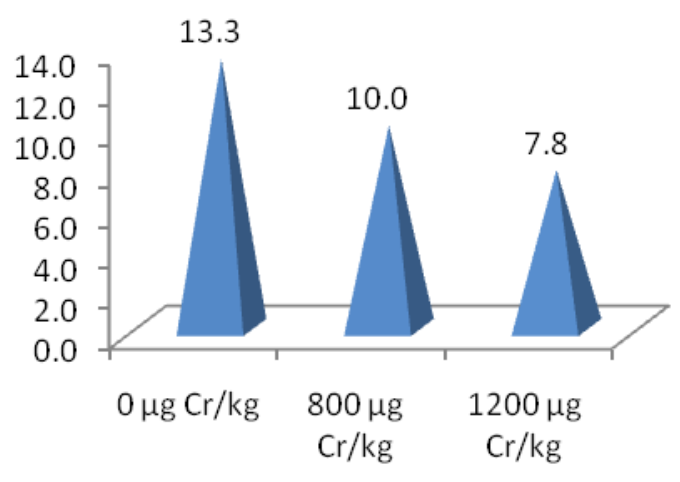

Effect of CrPic

Figure 2. Effect of CrPic on mortality rate

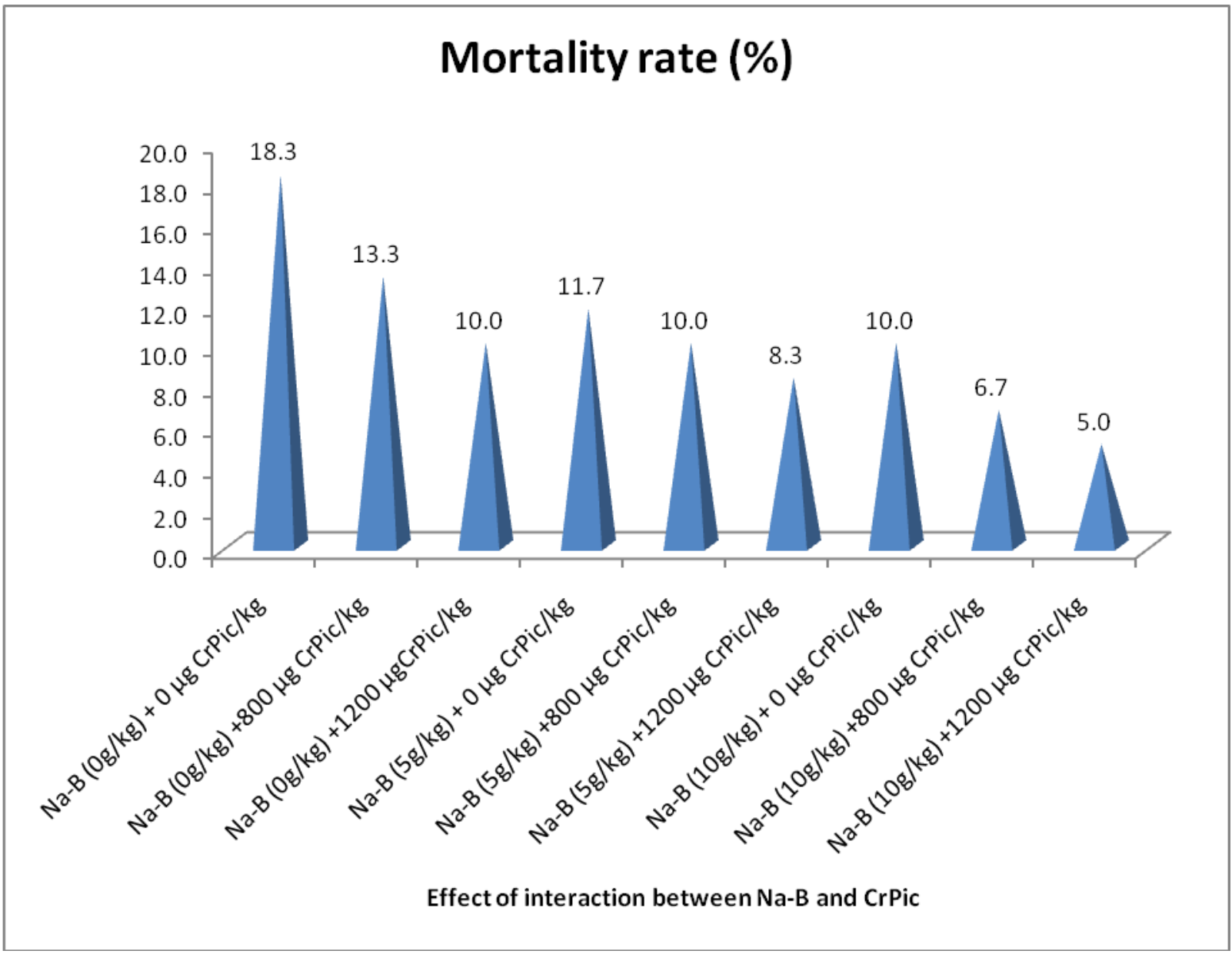

Figure 3. Effect of interaction between Na-B and CrPic on mortality rate 
Table (4): Antibody response and blood constituents $(\bar{X} \pm S E)$ of male Matrouh chicks as affected by different levels of dietary sodium bentonite and organic chromium and their interactions at the end of the experimental periods.

\begin{tabular}{|c|c|c|c|c|c|c|c|c|c|c|c|}
\hline \multicolumn{2}{|c|}{ Items } & SRBCs & $\begin{array}{c}\text { Total } \\
\text { protein } \\
\text { (g/dl) }\end{array}$ & $\begin{array}{l}\text { Albumin } \\
\text { (g/dl) }\end{array}$ & $\begin{array}{l}\text { Globulin } \\
\text { (g/dl) }\end{array}$ & GH & $\begin{array}{c}\text { Cholesterol } \\
\text { (mg/dl) }\end{array}$ & $\begin{array}{c}\text { Calcium } \\
\text { (mg/dl) }\end{array}$ & $\begin{array}{c}\text { T3 } \\
\text { (ng/dl) }\end{array}$ & $\begin{array}{c}\text { MDA } \\
(\mu \mathrm{mol} / \mathrm{ml})\end{array}$ & $\begin{array}{l}\text { GPX } \\
(\mathbf{U} / \mathbf{m l})\end{array}$ \\
\hline \multirow{5}{*}{\multicolumn{2}{|c|}{$\begin{array}{l}\text { SB }(\mathrm{g} / \mathrm{kg}): \\
0 \\
5 \\
10 \\
\mathrm{Cr} / \mathrm{Kg} \text { diet } \\
(\mu \mathrm{g}) . \\
0\end{array}$}} & NS & NS & NS & * & NS & NS & NS & * & $* *$ & * \\
\hline & & $4.73 \pm 0.19$ & $4.71 \pm 0.11$ & $2.26 \pm 0.10$ & $2.51 \pm 0.04^{\mathrm{b}}$ & $1.76 \pm 0.10$ & $128.07 \pm 5.86$ & $14.05 \pm 0.24$ & $4.47 \pm 0.35^{\mathrm{b}}$ & $2.86 \pm 0.12^{\mathrm{a}}$ & $46.94 \pm 2.24^{b}$ \\
\hline & & $4.80 \pm 0.21$ & $4.87 \pm 0.11$ & $2.35 \pm 0.08$ & $2.56 \pm 0.06^{\mathrm{ab}}$ & $1.82 \pm 0.08$ & $125.47 \pm 5.22$ & $14.3 \pm 0.42$ & $4.92 \pm 0.29^{\mathrm{ab}}$ & $2.73 \pm 0.15^{\mathrm{a}}$ & $55.48 \pm 1.77^{\mathrm{a}}$ \\
\hline & & $5.10 \pm 0.22$ & $5.12 \pm 0.20$ & $2.39 \pm 0.09$ & $2.73 \pm 0.15^{\mathrm{a}}$ & $1.91 \pm 0.12$ & $125.77 \pm 3.45$ & $14.75 \pm 0.26$ & $5.82 \pm 0.33^{\mathrm{a}}$ & $2.23 \pm 0.12^{\mathrm{b}}$ & $52.98 \pm 1.78^{\mathrm{a}}$ \\
\hline & & $* *$ & $*$ & * & & $*$ & ** & NS & NS & NS & NS \\
\hline \multicolumn{2}{|c|}{8} & $4.35 \pm 0.06^{\mathrm{b}}$ & $4.59 \pm 0.12^{\mathrm{b}}$ & $2.13 \pm 0.08^{b}$ & $2.48 \pm 0.09^{b}$ & $1.62 \pm 0.09$ & $138.09 \pm 3.84^{\mathrm{a}}$ & $13.9 \pm 0.39$ & $4.77 \pm 0.35$ & $2.75 \pm 0.16$ & $53.75 \pm 1.76$ \\
\hline \multicolumn{2}{|l|}{800} & $4.98 \pm 0.07^{\mathrm{a}}$ & $5.01 \pm 0.14^{\mathrm{a}}$ & $2.43 \pm 0.07^{\mathrm{a}}$ & $2.60 \pm 0.09^{\mathrm{ab}}$ & $\begin{array}{c}1.89 \pm 0.1 \\
\mathrm{ab}\end{array}$ & $125.97 \pm 3.65^{\mathrm{b}}$ & $14.59 \pm 0.29$ & $5.11 \pm 0.40$ & $2.61 \pm 0.16$ & $51.8 \pm 2.36$ \\
\hline \multicolumn{2}{|l|}{1200} & $5.30 \pm 0.08^{\mathrm{a}}$ & $5.10 \pm 0.16^{\mathrm{a}}$ & $2.44 \pm 0.09^{\mathrm{a}}$ & $2.72 \pm 0.1^{\mathrm{a}}$ & $\begin{array}{c}1.98 \pm 0.08 \\
\mathrm{a}\end{array}$ & $115.25 \pm 3.63^{b}$ & $14.61 \pm 0.23$ & $5.33 \pm 0.36$ & $2.46 \pm 0.15$ & $49.86 \pm 2.55$ \\
\hline \multicolumn{2}{|c|}{$\begin{array}{l}\text { Interaction } \\
\text { effects: }\end{array}$} & NS & NS & & $* *$ & NS & NS & & NS & NS & NS \\
\hline $\begin{array}{c}\mathrm{SB} \\
(\mathrm{g} / \mathrm{kg})\end{array}$ & $\begin{array}{c}\mathrm{Cr} / \mathrm{Kg} \\
(\mu \mathrm{g})\end{array}$ & & & & & & & & & & \\
\hline \multirow{4}{*}{0} & 0 & $4.46 \pm 0.38$ & $4.59 \pm 0.23$ & $2.02 \pm 0.19$ & $2.61 \pm 0.02^{\mathrm{bc}}$ & $1.55 \pm 0.19$ & $146.54 \pm 5.85$ & $13.73 \pm 0.51^{b c}$ & $4.3 \pm 0.63$ & $3.07 \pm 0.22$ & $52.11 \pm 3.51$ \\
\hline & 800 & $4.81 \pm 0.39$ & $4.73 \pm 0.19$ & $2.34 \pm 0.14$ & $2.42 \pm 0.06^{\mathrm{cd}}$ & $1.83 \pm 0.14$ & $125.29 \pm 6.07$ & $14.06 \pm 0.39^{\mathrm{abc}}$ & $4.49 \pm 0.75$ & $2.85 \pm 0.16$ & $46.01 \pm 3.77$ \\
\hline & 1200 & $4.91 \pm 0.30$ & $4.81 \pm 0.22$ & $2.41 \pm 0.11$ & $2.49 \pm 0.07^{\mathrm{cd}}$ & $1.89 \pm 0.18$ & $112.39 \pm 6.51$ & $14.34 \pm 0.42^{\mathrm{ab}}$ & $4.62 \pm 0.66$ & $2.65 \pm 0.18$ & $42.70 \pm 3.26$ \\
\hline & 0 & $4.12 \pm 0.19$ & $4.69 \pm 0.16$ & $2.15 \pm 0.11$ & $2.59 \pm 0.02^{\mathrm{bc}}$ & $1.67 \pm 0.08$ & $136.99 \pm 6.01$ & $12.90 \pm 0.42^{\mathrm{c}}$ & $4.69 \pm 0.57$ & $2.81 \pm 0.23$ & $55.48 \pm 3.29$ \\
\hline \multirow[t]{3}{*}{5} & 800 & $5.04 \pm 0.25$ & $4.94 \pm 0.24$ & $2.45 \pm 0.14$ & $2.48 \pm 0.16^{\mathrm{cd}}$ & $1.84 \pm 0.16$ & $128.19 \pm 8.82$ & $15.39 \pm 0.38^{\mathrm{a}}$ & $4.92 \pm 0.64$ & $2.76 \pm 0.35$ & $56.76 \pm 3.27$ \\
\hline & 1200 & $5.23 \pm 0.20$ & $4.98 \pm 0.21$ & $2.43 \pm 0.13$ & $2.60 \pm 0.06^{\mathrm{bc}}$ & $1.95 \pm 0.16$ & $111.24 \pm 6.39$ & $14.59 \pm 0.36^{\mathrm{ab}}$ & $5.15 \pm 0.48$ & $2.63 \pm 0.25$ & $54.19 \pm 3.77$ \\
\hline & 0 & $4.48 \pm 0.28$ & $4.49 \pm 0.27$ & $2.21 \pm 0.12$ & $2.23 \pm 0.20^{\mathrm{d}}$ & $1.64 \pm 0.21$ & $130.74 \pm 6.59$ & $15.05 \pm 0.42^{\mathrm{ab}}$ & $5.31 \pm 0.68$ & $2.37 \pm 0.24$ & $53.65 \pm 3.31$ \\
\hline \multirow[t]{2}{*}{10} & 800 & $5.07 \pm 0.26$ & $5.35 \pm 0.17$ & $2.48 \pm 0.16$ & $2.89 \pm 0.01^{\mathrm{ab}}$ & $2.00 \pm 0.23$ & $124.44 \pm 6.42$ & $14.31 \pm 0.43^{\mathrm{ab}}$ & $5.91 \pm 0.62$ & $2.2 \pm 0.18$ & $52.61 \pm 3.54$ \\
\hline & 1200 & $5.75 \pm 0.18$ & $5.51 \pm 0.26$ & $2.47 \pm 0.19$ & $3.06 \pm 0.14^{\mathrm{a}}$ & $2.09 \pm 0.12$ & $122.14 \pm 6.19$ & $14.88 \pm 0.51^{\mathrm{ab}}$ & $6.22 \pm 0.46$ & $2.11 \pm 0.24$ & $52.67 \pm 3.74$ \\
\hline
\end{tabular}

Means having different letters in the same column are significantly different $\quad *=(\mathrm{P}<0.05), \quad * *=(\mathrm{P}<0.01)$; NS= Not significant 
Table (5): Economic efficiency of male Matrouh chicks as affected by different levels of dietary sodium bentonite and organic chromium and their interactions at the end of the experimental periods.

\begin{tabular}{|c|c|c|c|c|c|c|c|c|c|c|c|}
\hline \multicolumn{2}{|c|}{ Items } & $\begin{array}{c}\text { Weight } \\
\text { gain } \\
(\mathbf{k g})\end{array}$ & $\begin{array}{l}\text { Price/kg } \\
\text { (LE) }\end{array}$ & $\begin{array}{c}\text { Total } \\
\text { revenue } \\
\text { chick } \\
(\text { LE) }\end{array}$ & $\begin{array}{c}\text { Total } \\
\text { feed } \\
\text { intake/ } \\
\text { chick } \\
\text { (kg) }\end{array}$ & $\begin{array}{c}\text { Price/Kg } \\
\text { feed } \\
\text { (LE) }\end{array}$ & $\begin{array}{l}\text { Total feed } \\
\text { cost/ chick } \\
\text { (LE) }\end{array}$ & $\begin{array}{c}\text { Fixed } \\
\text { chicks } \\
\text { (LE) }\end{array}$ & $\begin{array}{l}\text { Total } \\
\text { cost } \\
\text { chick } \\
(\mathrm{LE})\end{array}$ & $\begin{array}{c}\text { Net } \\
\text { revenue/ } \\
\text { chick }(\mathbf{L E})\end{array}$ & $\begin{array}{l}\text { Economic } \\
\text { efficiency } \\
\text { (EEF) }\end{array}$ \\
\hline \multicolumn{2}{|c|}{$\begin{array}{l}\mathrm{SB}(\mathrm{g} / \mathrm{kg}): \\
0 \\
5 \\
10 \\
\mathrm{Cr} / \mathrm{Kg} \operatorname{diet}(\mu \mathrm{g}) . \\
0 \\
800 \\
1200 \\
\text { Interaction effects: }\end{array}$} & $\begin{array}{l}0.732 \\
0.793 \\
0.786 \\
\\
0.726 \\
0.788 \\
0.797\end{array}$ & $\begin{array}{l}20.0 \\
20.0 \\
20.0 \\
\\
20.0 \\
20.0 \\
20.0\end{array}$ & $\begin{array}{l}14.637 \\
15.859 \\
15.721 \\
\\
14.516 \\
15.759 \\
15.943\end{array}$ & $\begin{array}{l}3.002 \\
2.993 \\
2.942 \\
\\
3.015 \\
2.959 \\
2.962\end{array}$ & $\begin{array}{l}4.10010 \\
4.10610 \\
4.11210 \\
4.10600 \\
4.10612 \\
4.10618\end{array}$ & $\begin{array}{l}12.307 \\
12.290 \\
12.096 \\
\\
12.380 \\
12.150 \\
12.163\end{array}$ & $\begin{array}{l}2.000 \\
2.000 \\
2.000 \\
\\
2.000 \\
2.000 \\
2.000\end{array}$ & $\begin{array}{l}14.307 \\
14.290 \\
14.096 \\
\\
14.380 \\
14.150 \\
14.163\end{array}$ & $\begin{array}{c}* * \\
0.330^{\mathrm{b}} \\
1.569^{\mathrm{a}} \\
1.625^{\mathrm{a}} \\
*^{*} \\
0.136^{\mathrm{b}} \\
1.609^{\mathrm{a}} \\
1.779^{\mathrm{a}}\end{array}$ & $\begin{array}{c}* * \\
2.192^{\mathrm{b}} \\
9.754^{\mathrm{a}} \\
9.349^{\mathrm{a}} \\
* * \\
0.556^{\mathrm{b}} \\
9.946^{\mathrm{a}} \\
10.793^{\mathrm{a}}\end{array}$ \\
\hline $\begin{array}{c}\text { SB } \\
(\mathrm{g} / \mathrm{kg})\end{array}$ & $\begin{array}{c}\mathrm{Cr} / \mathrm{Kg} \\
(\mu \mathrm{g}) \\
0 \\
800 \\
1200 \\
0 \\
800 \\
1200 \\
0 \\
800 \\
1200 \\
\end{array}$ & $\begin{array}{l}0.719 \\
0.739 \\
0.738 \\
0.773 \\
0.796 \\
0.810 \\
0.686 \\
0.829 \\
0.843 \\
\end{array}$ & $\begin{array}{l}20.0 \\
20.0 \\
20.0 \\
20.0 \\
20.0 \\
20.0 \\
20.0 \\
20.0 \\
20.0 \\
\end{array}$ & $\begin{array}{l}14.372 \\
14.784 \\
14.755 \\
15.453 \\
15.916 \\
16.210 \\
13.722 \\
16.576 \\
16.864 \\
\end{array}$ & $\begin{array}{l}2.963 \\
3.022 \\
3.019 \\
3.121 \\
2.905 \\
2.953 \\
2.961 \\
2.949 \\
2.914 \\
\end{array}$ & $\begin{array}{l}4.10000 \\
4.10012 \\
4.10018 \\
4.10600 \\
4.10612 \\
4.10618 \\
4.11200 \\
4.11212 \\
4.11218 \\
\end{array}$ & $\begin{array}{l}12.149 \\
12.392 \\
12.379 \\
12.816 \\
11.930 \\
12.126 \\
12.175 \\
12.128 \\
11.985 \\
\end{array}$ & $\begin{array}{l}2.000 \\
2.000 \\
2.000 \\
2.000 \\
2.000 \\
2.000 \\
2.000 \\
2.000 \\
2.000 \\
\end{array}$ & $\begin{array}{l}14.149 \\
14.392 \\
14.379 \\
14.816 \\
13.930 \\
14.126 \\
14.175 \\
14.128 \\
13.985 \\
\end{array}$ & $\begin{array}{c}* * \\
0.223^{\mathrm{b}} \\
0.393^{\mathrm{b}} \\
0.375^{\mathrm{b}} \\
0.637^{\mathrm{b}} \\
1.985^{\mathrm{a}} \\
2.084^{\mathrm{a}} \\
-0.453^{\mathrm{b}} \\
2.448^{\mathrm{a}} \\
2.879^{\mathrm{a}} \\
\end{array}$ & $\begin{array}{c}* * \\
1.402^{\mathrm{b}} \\
2.635^{\mathrm{b}} \\
2.538^{\mathrm{b}} \\
4.025^{\mathrm{b}} \\
12.460^{\mathrm{a}} \\
12.777^{\mathrm{a}} \\
-3.760 \\
14.745^{\mathrm{a}} \\
17.063^{\mathrm{a}} \\
\end{array}$ \\
\hline
\end{tabular}

Total revenue $=$ Weight gain $(\mathrm{kg}) /$ chick X Price/kg (LE). Total cost chick (LE) $=$ Total feed cost/ chick (LE)+ Fixed chicks (LE)

Net revenue/ chick $(\mathrm{LE})=$ Total revenue chick $(\mathrm{LE})$ - Total cost chick (LE) EEF= Net revenue/ chick (LE)/ Total cost chick (LE) X 100

Means having different letters in the same column are significantly different $\quad *=(\mathrm{P}<0.05), \quad * *=(\mathrm{P}<0.01)$; NS= Not significant 


\section{REFERENCES}

Abdallah, E. A.; Abdel Samad, M.H. and Abdel latif, A.M., 2013. Effect of supplementing diet with chromium picolinate on productive, reproductive, physiological performance and immune response of golden montazah chickens. Egypt. Poult. Sci., Vol (33) (IV): 751767.

Abdel-Motelib, A.; Kader ZaiNa-B Abdel; Ragab, Y.A. and Maha Mosalamy, 2011. Suitability of a miocene bentonite from north western desert of Egypt for pharmaceutical use. Appl. Clay Sci.., 52 :140-144.

Aghashahi, A.R.; Hosseinijangjoo, S.H.; Sadeghipanah, H. and Hosseini, S.A. 2015. Effect of various type of bentonite (montmorillonite) on ascites-related physiologic and metabolic factors in broilers. Iranian Journal of Appl. Anim.Sci., 5(2), 423-430.

Akbarian, A.; Julian, A.; Kermanshahi, H.; Gilani, A. and Moradi, S. 2012. Influence of turmeric rhizome and black pepper on blood constituents and performance of broiler chickens. African J. Biotechnol., 11, 8606-8611.

Al-Bandr, K. Lama; Dhia K. Ibrahim and Essa H. Al-Mashhadani, 2010. Effect of supplementing different sources of chromium to diet on some physiological traits of broiler chickens. Egypt. Poult. Sci., Vol (30) (II): 397413.

Anandhi, M.; Mathivanan, R.; Viswanathan, $K$. and Mohan, $B$. 2006. Dietary inclusion of organic chromium on production and carcass characteristics of broilers. Int. J. Poult. Sci., 5:880-884.

Anderson, R.A. 1999. Chromium as an essential nutrient. The chromium file from the International Development Association N.6 September 45 Rue de Lisbone, 75008 Paris.

Aslanian, A.; Noori, K.; Abolfazl, A.D.; Habib, A.S.; Shahnaz, R.; Naser, M.S.
2011. Evaluate the effect of $\mathrm{Cr}$ methionine on performance and serum metabolite in growing-finishing male broiler. J Basic Appl. Sci. Res., 1(11): 2442-2448.

Assesm L. and Zhu H. 2007. $\mathrm{Cr}$ toxicological overview, Institute of Environment and Health Cranfield University.

Bahrami, A.; Maine, M. M.; Ghazi, S. H. and Targhibi, M. R. 2012. The effect of different levels of organic and inorganic chromium supplementation on immune function of broiler chicken under heat-stress conditions. J. Appl. Poult. Res., 21:209-215.

Barmase, B.S.; Devegowda, G. and Devurkar, U. 1990. Reversal of aflatoxicosis through dietary adsorbents in broiler chickens. Proc. 13th Annual Conf. Symp. Indian Poult Sci. Assoc., Bombay, 20-22

Borgs, P., and Mallard B. A. 1998. Immune-endocrine interactions in agricultural species: Chromium and its effect on health and performance. Domest. Anim. Endocrinol. 15:431-438.

Cant, J.P.; McBride, B.W. and Croom, W. 1996. The regulation of intestinal metabolism and its impact on whole animal energetics. J. Anim. Sci., 74, 2541-2553.

Chen, G.; Liu, P.; Pattar, G. R.; Tackett, L.; Bhonagiri, P.; Strawbridge, A. B. and EImendorf J. S. 2006. Chromium activates glucose transporter 4 trafficking and enhances insulin-stimulated glucose transport in 3T3-L1 adipocytes via a cholesterol dependent mechanism. Mol. Endocrinol. 20:857-870.

Clodfelder, B. J.; Chang, C. and Vincent, J. B. 2004. Absorption of the biomimetic chromium cation triaqua- $\mu 3$ oxo- $\mu$ - hexapropionatotrichromium (III) in rats. Biol. Trace Elem. Res. 98:159169.

Damiri, H.; Chaji, M.; Bojarpour M.; Eslami M. and Mamoei M., 2012. 
Effect of different sodium bentonite levels on performance, carcass traits and passage rate of broilers. Pak Vet J., 32(2): 197-200.

Duncan, D.B. 1955. Multiple range and multiple F tests. Biometrics, 11:1-42.

El-Abd M. Niamat, 2014. Effect of feed supplemented with different levels of sodium bentonite on Japanese quail performance. Egypt. Poult. Sci., Vol (34) (III): 705-713.

El-Hommosany, Y.M. 2008. Study of the physiological changes in blood chemistry, humoral immune response and performance of quail chicks fed supplemental chromium. Int J. of Poult Sci., 7 (1): 40-44.

El-Kaiaty, A.M.; Fatma, R.M.; Eman, M. A. and Abeer, A.M. E. 2005. Beneficial impact of organic chromium supplementation of broiler diets on growth performance, some blood constituents and immunological status. Egypt. J. Nutr. and Feeds.8 (1): 737759.

Eshra, A.A. 2005. Physiological and immunological and probiotic in broiler. M.V.Sc. Thesis, Dep. Of Animal Production, Fac. Agriculture, Cairo University.

Eya , J.C.; Parsons, A. ; Haile, I. and Jagidi, P. 2008. Effects of dietary zeolites (bentonite and mordenite)

on the performance juvenile rainbow trout Onchorhynchus myskis. Aust J.

Basic Appl. Sci., 2: 961-967.

Fatouh, M. H. A.; Awad A. L.; and Ghonim, A. I. A. 2012. Effect of dietary sodium bentonite supplementation on laying performance of Domyati and Kampell ducks. Egypt. Poult. Sci., Vol (32) (III): (497-514).

Ibraham, K. A. 2005. Effects of dietary chromium supplementation on growth performance, carcass characteristics and some blood parameters of broilers. Egypt. Poult Sci., 25: 167-185.

Ibrahim, D. K., Essa H. Al-Mashhadani and Luma K. Al-Bandr 2010. Effect of supplementing different levels of chromium yeast to diet on broiler chickens on some physiological traits. Pakistan J. of Nut. 9 (10): 942-949.

Jackson, A. R., S. Powell, S. Johnston, J. L. Shelton, T. D. Binder, F. R. Valdez, and L. L. Southern. 2008. The effect of chromium propionate on growth performance and carcass traits in broilers. J. Appl. Poult. Res. 17:476481.

Khanedar, I.; Vakili, R. and Zakizadeh S., 2012. Effects of two kinds of bentonite on the performance, blood biochemical parameters, carcass characteristics and tibia ash of broiler chicks. Global Vet., 9 (6): 720-725.

Lien, T. F; Hornig, Y.M and Yang, K.H. 1999.Performance, serum characteristics, carcass traits and lipid metabolism of broilers as affected by supplement of chromium picolinate. Br Poult Sci., 40 (3): 357-63.

Miazzo, R.; Peralta, M.F.; Magnoli, C.; Salvano, M.; Ferrero, S.; Chiacchiera, S.M.; Carvalho, E.C.Q.; Rosa, C.A.R. and Dalcero, A., 2005. Efficacy of sodium bentonite as a detoxifier of broiler feed contaminated with aflatoxin and fumonisin. Poult. Sci., 84: 1-8.

Mohammed, H.H.; El-Sayed, B.M.; Abd El-Razik, W.M.; Ali, M.A. and Abd El-Aziz, R.M. 2014. The Influence of Chromium Sources on Growth Performance, Economic Efficiency, Some Maintenance Behaviour, Blood Metabolites and Carcass Traits in Broiler Chickens. Global Veterinaria, 12 (5): 599-605.

Moonsie-Shageer, S. and Mowat D. N. 1993. Effect of level of supplemental chromium on performance, serum constituents, and immune status of stressed feeder calves. J. Anim. Sci., 71: 232-238.

Mostafa, N.M., 2007. Effect of organic and inorganic selenium or chromium on productive performance and immunity 
of broilers, M.V.Sc. Thesis, Fac. Vet. Med; Cairo Uni.

NRC 1994. Nutrient Requirements of Poultry.9th rev. ed. National Academy Press, Washington, DC.

Onderci M.; Sahin K.; Sahin N.; Cikim G.; Vijaya, J. and Kucuk, O.2005. Effects of dietary combination of chromium and biotin on growth performance, carcass characteristics, and oxidative stress markers in heatdistressed Japanese quail.Biol Trace Elem Res. 106 (2):165-76.

Pacheco, P.D.G.; Stradiotti , A.C.; Siloto , E.V.; Alvarenga , P.V.A.; Putarov , T.C. ; Sartori D.R.S. ; Sartori ，J.R. ; Vicentini-Paulino , M.L.M. ; Piccinin , A. and Pinherio, D.F. 2012. Effect of organic $\mathrm{Cr}$ supplementation and energy levels on digestive enzyme activities in laying hens. Poult. Sci., 91 (Suppl. 1). 144.

Pasha, T. N.; Mahmood, A.; Khattak, F.M.; Jabbar, M.A. and Khan, A.D., 2008. The effect of feed supplemented with different sodium bentonite treatments on broiler performance. Turk. J. Vet. Anim. Sci., 32: 245-248.

Preuss, H. G.; Grojec, P. L.; Lieberman, S. and Anderson, R. A., 1997. Effects of different chromium compounds on blood pressure and lipid peroxidation in spontaneously hypertensive rats. Clin. Nephrol., 47: 325-330.

Rosebrough, R.W. and Steele, N.C. 1981. Effect of supplemental dietary chromium or nicotic acid on carbohydrate metabolism during basal, starvation and refeeding periods in poults. Poult. Sci., 60:407-11.

Safaeikatouli, M. ; Jafariahangari, Y. and Baharlouei A. 2010. Effects of dietary inclusion of sodium bentonite on biochemical characteristics of blood serum in broiler chickens. Int. J. Agric. Biol., 12, 877-880.

Sahin, K.; Sahin, N.; Onderci, M.; Gursu, F. and Cikim G. 2002. Optimal dietary concentration of chromium for alleviating the effect of heat stress on growth, carcass qualities, and some serum metabolites of broiler chickens. Biol. Trace Elem. Res., 89:53-64.

Salari, S.; Kermanshahi, H. and Nasiri Moghaddam, H. 2006. Effect of sodium bentonite and comparison of pellet vs. mash on performance of broiler chickens. Int. J. Poult. Sci., 5, 3134.

Samanta, S.; Haldar, S.; Bahadur, V. and Ghosh, T. 2008. Chromium picolinate can ameliorate the negative effects of heat stress and enhance performance, carcass and meat traits in broiler chickens by reducing the circulatory cortisol level. J. Sci. Food Agric. 88:787-796.

SAS Institute., 2004. SAS / DSTAT User S Guide. SAS Institute Inc., Cary,Nc.

Tawfeek, S. S.; Abdella, K. M. and Youssef, I. M. 2014. The effect of dietary supplementation of some antioxidants on performance, oxidative stress and blood parameters in broilers under natural summer condition. J. World's Poult. Res., 4(1): 10-14.

Tauqir, N.A. and Nawaz, H., 2001. Performance and economics of broiler chicks fed on rations supplemented with different levels of sodium bentonite. Int. J. Agri. Biol., 3: 149-150.

Toghyani, M.; Zarkesh, S.; Shivazad, M. and Gheisari, A. 2007. Immune responses of broiler chicks fed chromium picolinate in heat stress condition. J. Poult. Sci., 44:330-334.

Trout, J. M.; Mashaly, M. M. and Siegel, H. S. 1996. Changes in blood and spleen lymphocyte populations following antigen challenge in immature male chickens. Br. Poult. Sci., 37: 819-827.

Uyanik, F.; Atasever, A.; Ozdamar, S. and Aydin, F. 2002. Effects of dietary chromium chloride supplementation on performance, some serum parameters and immune response in broiler. Biol. Trace Elem. Res., 90: 99-115. 
Valenzuela, A. 1991. The biological significance of malondialdehyde determination in the assessment of tissue oxidative stress. Life Sci., 48: 301-309.

Weser, U. and Koolman, U.J. 1969. Untersuchungen zur protein biosynthese in Rattenieber zellerkernen.Hoppe Seyler's Z. Physiol. Chem. 350:12731278.

Weydert, C.J. and Cullen, J.J. 2010. Measurement of superoxide dismutase, catalase and glutathione peroxidase in cultured cells and tissue. Nature Protocols., 5:51-66.

Zaki, M.S., Nevin E. Sharaf., Hend Rashed., Susan O. Mostafa and Olfat M. Fawzi2008. Diminution of aflatoxicosis in Tilapia nioltica fish by dietary supplemention with Fix in toxin and Nigella sativa oil. AmericanEurasian J. Agric. \& Environ. Sci., 3 (2): 211-215.

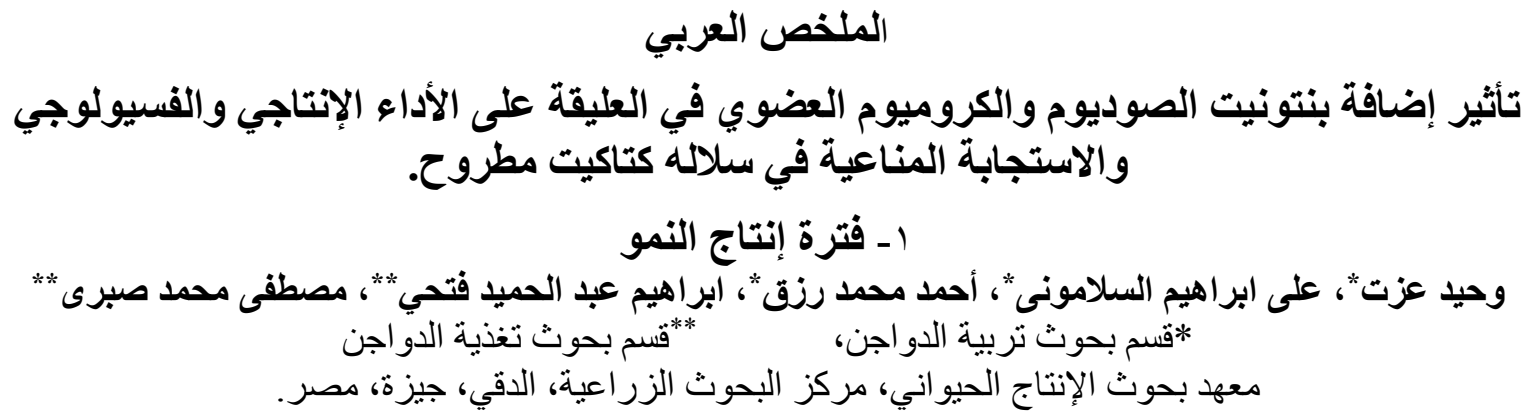

الهدف الرئيسي من هذه الدر اسة تقييم تأثثير إضافة مستويات مختلفة من بنتونيت الصوديوم ( •، 0، ا 1 جم / كجم عليقه)

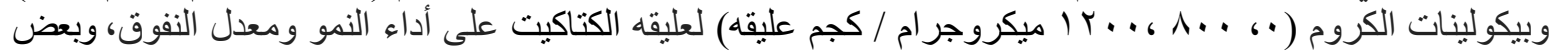

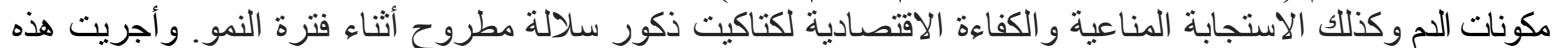

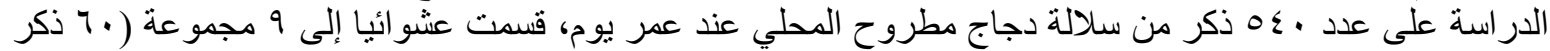

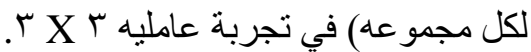

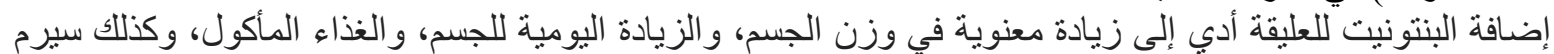

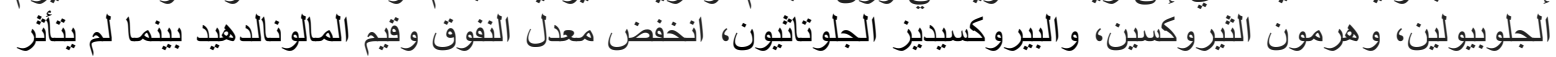

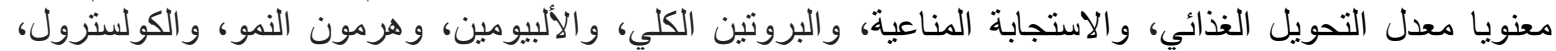

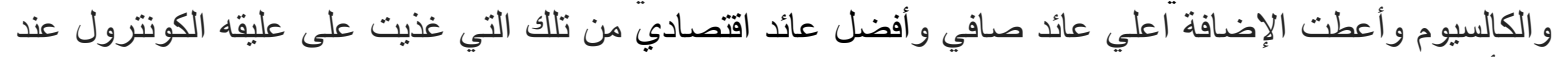
rا بالسبوع من العمر.

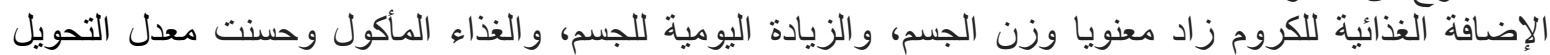

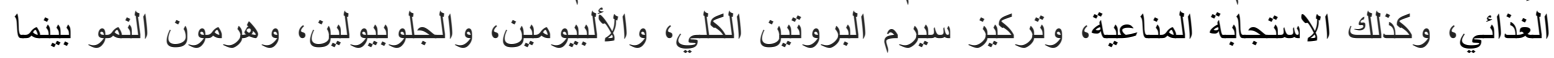

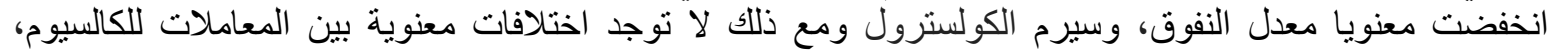

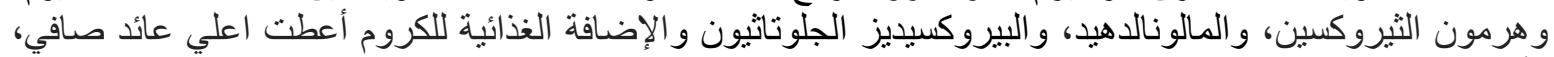

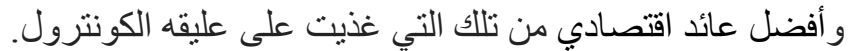

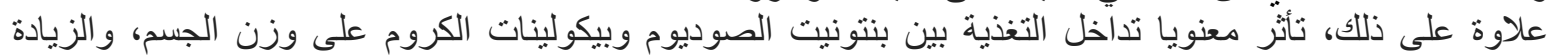

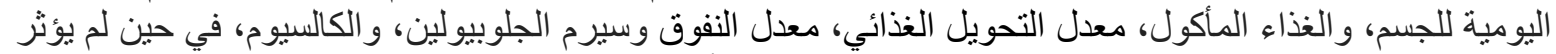

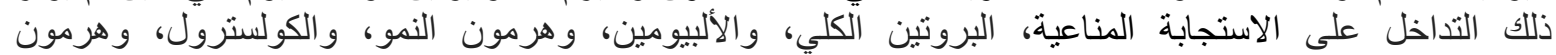

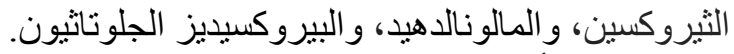

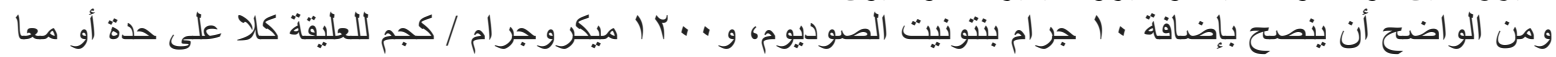

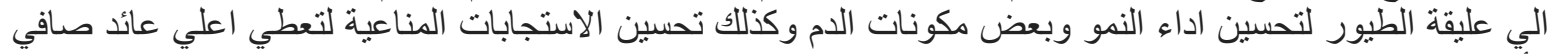
و أفضل كفاءة اقتصادية خلال فترة نمو كتاكيت ذكور مطرو لكور ل 